\title{
An Analysis of Accountability Concepts for Open Development
}

\author{
Caitlin Bentley $^{(\bowtie)}(\mathbb{D}$ \\ Singapore Internet Research Centre, Nanyang Technological University, \\ Singapore, Singapore \\ cmbentley@ntu.edu.sg
}

\begin{abstract}
Open development is the public, networked sharing of communication and information resources towards a process of positive social transformation. Open development likewise imposes a challenge, because new actors, practices and problems of inequality are introduced. Accountability at its core is meant to redress issues of power and inequality [1], thus offering potential to improve open development processes and initiatives. However, the distinct and innovative characteristics of open processes render some concepts of accountability inadequate. This article compares three purposes and perspectives on accountability for their relevance to open development. The purpose of which is to suggest future areas of research and theoretical development in this field.
\end{abstract}

Keywords: Open development $\cdot$ Accountability $\cdot$ ICT4D

\section{Introduction}

This paper adopts two key ideas to frame open development which are drawn from Smith and Seward [2] and Reilly and Smith [3]. Open development can be defined in terms of what it is for, and how it works. In terms of how it works, Smith and Seward [2] outline three processes that set open development apart from other forms of ICT supported interaction: open consumption (e.g. using, remixing, and repurposing content), open distribution (e.g. sharing and republishing content) and open production (e.g. peer production). These processes explain how and why particular arrangements of people, technology and content offer distinct opportunities for development. Second, open development can be defined in terms of what it is for. Reilly and Smith [3], in accordance with Sen [4], argue that open development, like human development, is the expansion of freedom. However, scholars also emphasise that institutional structures of society play a significant role in shaping the freedom of groups and individuals [5, 6].

A debate has occurred amongst scholars in this field regarding whether or not what open processes are lead to what open development is for. Some have argued that open processes enable radical transformations away from bureaucratic modes of doing development, towards freer, less exclusive arrangements [3, 7]. In contrast, other scholars

The original version of this chapter was revised: The erratum to this chapter is available at https:// doi.org/10.1007/978-3-319-59111-7_72

(C) The Author(s) 2017

J. Choudrie et al. (Eds.): ICT4D 2017, IFIP AICT 504, pp. 793-802, 2017.

DOI: 10.1007/978-3-319-59111-7_64 
argue that open processes replicate wider structures of power and inequality within society, which open processes do not influence in and of themselves [8,9]. The middle ground is that due to the complexity and flexibility of open processes, a wide spectrum of outcomes occurs. Outcomes are therefore contingent on a variety of contextual factors. Thus, there is a need to differentiate how and why certain development actors, particularly the poorest and most marginalised, may be positively or negatively affected.

Accountability is a concept that can potentially be used to understand and influence whether open processes are having positive development effects. Accountability can be broadly seen as the tools and processes that protect and empower individuals' opportunity to experience freedom $[1,10,11]$. However, what accountability means, and how it operates has not been explored within open development in detail. Much of the discourse on accountability in open development has focused on making use of new technology to hold development actors, such as governments, to account. ICT tools created to collect feedback directly from citizens can change accountability relationships, such that new channels between development aid recipients and the institutions serving them have been created [12]. Governments making public data available for free, hope to deliver greater transparency and accountability towards citizens [13, 14]. However, the links between accountability and open development are far more pervasive.

Yet, accountability is a contested concept, and there is no set of accountability concepts that apply universally. This paper addresses a gap in the literature by outlining three purposes and three groups of concepts of accountability, through a review of the literature, which seem pertinent to explore further in the area of open development. I provide suggestions regarding the types of concepts and purposes as a means to begin discussions, and to develop a future research agenda in this area.

\section{Comparing Accountability Concepts for Open Development}

Accountability, like open development, has also been theorised as both processes and outcomes [15-17]. I begin by outlining three purposes of accountability, which aid in differentiating potential applications of accountability to open development. These draw out the justification for focusing the conceptual review of accountability according to three themes: relationship-based concepts, practice and actor-based concepts, and normative or tool-based concepts. The subsections go into more detail regarding these themes of accountability concepts, and analyse them for their suitability for open development.

A fundamental debate in accountability literature centres on the role of individuals in governing their own lives [18, 19]. When people are directly involved in governing aspects of their lives, they are more likely to make choices that suit their own needs [18]. However, Cooke and Kothari's [20] argue that instrumentalising participation has a detrimental effect. This is especially true when people have limited opportunity to make decisions about how and why they contribute and/or benefit. Ebrahim [15] therefore posited that higher levels of participation, where individuals have full decision-making power and control over their actions constitutes greater accountability. Likewise, when individuals have fewer options to choose how to participate, accountability is weakened. 
There is a parallel between this proposition and the technical design of open processes, because there are usually no imposed restrictions on who or how people contribute. Thus, the assumption is that individuals have the opportunity to govern how they use and benefit from their participation in open processes. However, in practice, empirical research has demonstrated that poor and marginalised people face many structural barriers that inhibit their participation in open processes [21]. Hence, it is worthwhile to explore additional purposes of accountability for open development.

Alternatively, responsiveness is a form of accountability that considers the perspectives of individuals and groups in need first and foremost [22]. Politicians are presumably re-elected when they listen and respond to the needs of their constituents [23] (perhaps a false truth these days!). The same principle holds true for actors and roles across different kinds of institutions. Empirical research has focused on analysing how responsiveness is enacted in private, public and third sector institutions [24-26]. However, open processes can be enacted across institutions, having variable levels of consistency and structure. This characteristic poses a problem to use responsiveness as the primary basis of accountability within open development. For example, a high level of responsiveness might seem realistic for a teacher using or producing open educational resources for one classroom, but once those resources are released for public consumption the teacher might not have close relationships with external users of the content. Likewise, a teacher facilitating a Massive Open Online Course serving thousands of individuals is not likely going to be able to respond to all learners. In this case, it may be necessary to explore both tools and processes for responsiveness. For instance, a survey tool to collect and consolidate feedback could help her to respond to groups of needs. In general, the major concern with responsiveness development is that it fails to differentiate between active and passive actors. Active actors may not be ideally positioned to respond to passive actors. For example, open source software developers might not be in a position to understand the needs of passive users of their software. This implies a need to consider the role of actors and institutions who have obligations towards passive actors.

The last framing of accountability discussed is therefore obligation. Obligation refers to the normative and contractual terms of accountability and potential sanctions [1]. This includes legal and regulatory frameworks that outline clear institutional rules and expectations for open development. Obligation also refers to actors' duty, which is contingent on roles, formal and felt responsibilities, identities and relationships [27]. For instance, Handlykken [28] examined the impact of a government policy to adopt open source software, which has shown little effect in practice. There has also been a wealth of research on opening up government data, and instituting strategies to garner meaningful use of this data [29-31]. In particular, Gigler et al. [12] reported that new citizen feedback channels changed obligations of traditional development actors. Another example, Uber, a ride-sharing platform, came under fire in Pakistan for the corrupt practices of rental car agencies who use the platform to exploit cheap illiterate workers [32]. However, understanding, shaping and/or regulating the obligations of actors in certain circumstances within open processes is a nascent area. Moreover, in many instances, obligations may not need regulating or shaping, as most open processes may never grow to the scale of Uber or government. Yet, as Forte and Lampe [33] argued, open systems tend to have emergent social structures which shape 
obligations. This can also be problematic for open development when certain groups of people may tend to dominate and render the system highly unequal. This is why there is also a need to contemplate obligations in terms of individual responsibilities, and how people may come to develop obligations towards others and to their role within open processes.

In summary, the table below outlines key concerns according to three accountability purposes in open development. The questions in Table 1 are only meant to help to differentiate how accountability purposes and concerns might change across purposes and types of open processes. Whilst I do not attempt to answer each question specifically in the remainder of this paper due to length requirements and scope of this discussion, these questions framed my engagement with the three themes of accountability concepts in the remainder of the paper. I turn now to explore three groups of accountability concepts for their relevance to understand and influence the relationship between what open development is and what it is for.

Table 1. Key accountability concerns across purposes of accountability and open processes

\begin{tabular}{|c|c|c|c|}
\hline & Participation & Responsiveness & Obligation \\
\hline $\begin{array}{l}\text { Open } \\
\text { consumption } \\
\text { - Using } \\
\text { - Revising } \\
\text { - Remixing }\end{array}$ & $\begin{array}{l}\text { (1) Do people apply, not } \\
\text { only access resources? } \\
\text { (2) Can people choose } \\
\text { how to participate? }\end{array}$ & $\begin{array}{l}\text { (3) Do resources } \\
\text { respond to needs? } \\
\text { (4) Are the needs of } \\
\text { actors both directly } \\
\text { and indirectly } \\
\text { involved considered? }\end{array}$ & \multirow{3}{*}{$\begin{array}{l}\text { (5) What are the } \\
\text { conditions for access to, } \\
\text { and facilitation, } \\
\text { maintenance and } \\
\text { replenishment of } \\
\text { resources? } \\
\text { (6) What roles, identities } \\
\text { and responsibilities do } \\
\text { actors have and } \\
\text { experience? } \\
\text { (7) What social and } \\
\text { political structures } \\
\text { influence behaviours anc } \\
\text { actions? } \\
\text { (8) What liabilities and } \\
\text { sanctions will actors be } \\
\text { subjected to if they } \\
\text { do not uphold their } \\
\text { duties? }\end{array}$} \\
\hline $\begin{array}{l}\text { Open distribution } \\
\text { - Sharing } \\
\text { - Republishing }\end{array}$ & $\begin{array}{l}\text { (1), (2) and (9) Are } \\
\text { distribution platforms } \\
\text { accessible and } \\
\text { appropriate? }\end{array}$ & $\begin{array}{l}(3),(4) \text { and } \\
(10) \text { Does the } \\
\text { distribution platform } \\
\text { respond to user } \\
\text { needs and usability } \\
\text { requirements? }\end{array}$ & \\
\hline $\begin{array}{l}\text { Open production } \\
\text { - Peer production } \\
\text { - Crowdsourcing }\end{array}$ & $\begin{array}{l}(1),(2) \text { and }(11) \text { Do } \\
\text { people have the skills } \\
\text { and opportunity to } \\
\text { contribute in the ways } \\
\text { they see fit? }\end{array}$ & $\begin{array}{l}(3),(4) \text { and }(12) \\
\text { Does the production } \\
\text { process deliver the } \\
\text { required resources at } \\
\text { an acceptable } \\
\text { quality standard and } \\
\text { timeframe? }\end{array}$ & \\
\hline
\end{tabular}

\subsection{Relationship-Based Concepts}

Relationship-based theories of accountability tend to focus on what actors are owed by those responsible for fulfilling agreed upon commitments. Agency theory focuses on the principal-agent model such that a principal brokers a deal with an agent to deliver an artefact. Actors may have tangential interests than what the principal has asked for, and thus agents have an incentive to avoid accomplishing what was mutually agreed, and or to selectively share or hide information [34, 35]. Principals have an incentive to 
control known problems as a means to protect their brokered deal from known negative influences [34]. This accountability concept is highly transactional in nature because it emphasises conditions imposed on relationships to ensure that each actor is held to account, and that sanctions can be applied when actors do not fulfill their obligations.

This concept could be useful to understand how open development works because it assumes that actors are motivated by individual interest. Within open distribution and consumption processes, the underlying premise is that people are free to use resources in ways they see fit, which ignores the underlying interests of open distributors. Agency theory implies that open consumers (agents) have privileged information over their actions with these resources, whilst open distributors (principals) have authority over the provision of them. Principals may seek methods to control how resources are used to suit their own interests. Based on this notion, this theory might aid in researching all three accountability purposes as the interests of authoritative actors may skew participation, responsiveness, and their perceived obligations. A weakness of this theory is that relationships between actors, may be ambiguous, especially when there are many distributors involved. It is best used when there are well-established actors and relationships, as with Murillo's [13] application of this theory to open government initiatives in Latin American countries. Similarly, within open production processes, this theory may not be informative for highly decentralised open production processes and communities, especially when membership is in flux. A task-based scale may be the most appropriate application, as this theory might inform on why or why not actors may be motivated to contribute to a specific task.

In contrast, development scholars contextualised the principal-agent model to address the more realistic situation when actors have multiple accountabilities, not only between one principal and an agent [36, 37]. The idea is to identify multiple accountabilities across relationships in order to assess how actors prioritise certain accountability relationships over others. These relational concepts of accountability are more focused on determining power asymmetries between the actors, and how power influences the actors' choices to uphold their commitments. Whilst relational concepts of accountability are more realistic in development contexts and processes, as they can identify key pitfalls to watch out for, it is still problematic within cases where the actors are not well-known, or directly related, making it ambiguous to apply. Nevertheless, relational concepts draw attention to the need to recognise multiple relationships and how and why accountabilities are prioritised. These concepts seem to offer significant value for targeted analysis of specific relationships within open processes. However, identifying which relationships to study may be problematic. The next group offers insight into how relevant actors might be targeted.

\subsection{Practice- or Actor-Based Concepts}

The second group of concepts emphasises the contextual and situated nature of accountability. Theories within this group operate on the assumption that accountability is intertwined with its context, and are inseparable from other aspects of purposeful action [16, 38]. This means that theorists have focused on practices of accountability in certain settings, like organisations, public or educational institutions. Examining the 
practice perspective enables understanding how actors and organisations enact accountability, and the tools and procedures they make use of. Practice-based perspectives also shed light on the resultant structures and dynamics of accountability, thus dealing with complexity of relationships and multiple accountabilities. However, these concepts do not provide a means for comparing alternatives or understanding whether one way of doing is better than another [39]. Therefore, these concepts are advantageous for understanding how accountability functions in new, under-explored open processes and settings.

This perspective is particularly relevant for understanding accountability in new and innovative open processes. For instance, accountability in open production communities, many of which are self-organised and highly decentralised, is likely to be distinct from the institutional contexts mentioned above. Practice-based notions of accountability may also help organisations inform their understanding of how new open methods of working interact with existing practice. For example, many aid institutions have established funding programmes, institutional policies and procedures around the ethos of sharing their knowledge resources in open formats. This brought about new institutional contexts emphasising freedom and inclusion, but may also have knock-on effects in complementary aspects of its development work.

In a similar vein, researchers have also focused on the roles and identities of actors to frame accountability, and how these are constructed in context. Bovens [27] argued that actors experience five types of responsibilities which influence their contributions to accountability: (1) hierarchical responsibility (loyalty to superiors); (2) personal responsibility (relating to conscience and personal ethics); (3) social responsibility (relating to social norms and peers); (4) professional responsibility (profession and professional ethics); (5) civic (citizen and civic values). These dimensions seem particularly pertinent to organise an exploratory study of accountability in open processes because of the way that open processes involve multiple actors and contexts. For instance, the tendency to assume that open distribution models, like open government data initiatives, can be replicated and transported across contexts fails to acknowledge how people and institutions are shaped by different values, ethics and obligations. Actor-based concepts highlight the importance of understanding multiple perspectives within open processes. These concepts may also aid in exploring roles and responsibilities of new actors that have entered traditional development practice spheres. However, these concepts likewise have difficulty to establish normative aspects of what actors roles and responsibilities should be.

\subsection{Normative or Tool-Based Concepts}

Normative or tool-based concepts refer to objective standards and processes to oversee and entrench aspects of accountability. It is unlikely that an overarching accountability framework for open development is possible or desirable. Nevertheless, normative or tool-based concepts of accountability could be helpful under many sets of circumstances. To give an explanation of what types of norms or tools are possible, Bendell [40] outlines a list of tools such as legal and policy frameworks, elections, boards of officials, codes of conduct, certifications, ratings, summative reports, monitoring and 
evaluation, and dialogue and participation. At face value, some of these are more applicable to open development than others. First, elections, boards of officials, codes of conduct and certification imply a highly defined regulatory area because these accountability tools would likely emerge only after a substantial institutional base has been established. Therefore, governments, institutions, networks, communities and services that persist for long periods of time might be the most pertinent to consider for these types of accountability tools. However, as Handlykken's [28] discussion of open source policy implementation in South Africa mentioned above notes, policies do not always have the intended effects. Conceptualising accountability as a particular tool or normative framework, nevertheless, does enable greater cross-comparison. This indicates that research incorporating both practice-based and tool-based concepts might be valuable.

The remaining tools from the list, such as monitoring and evaluation, ratings, and dialogue are perhaps of wider significance at the present stage because these tools can be useful to a more heterogeneous group of actors and contexts. The benefit of accountability tools, such as monitoring and evaluation, is that the connections between what open development is and what it is for can be made explicit. For instance, Smith and Seward [2] state that open processes are socially-embedded, but they do not theorise the links between how open processes function and what they achieve. In contrast, Zheng and Stahl's [41] critical capability approach to open development enables the investigation of open processes in terms of explicit outcomes related to capabilities, human diversity, marginalisation and inclusion. The main issue with monitoring and evaluation is that this tool requires that an actor has the will or obligation to apply it. In contrast, many open production communities are instead quite decentralised and self-organising, implying that formative evaluations may never come to light. An interesting application to note is Sharp's [42] open source community heartbeat tool, which tracks and visualises statistics, showing how newcomers are integrated and contributing code. However, these sorts of tools have not been explored in depth, warranting further research on the matter.

\section{Conclusion}

Overall, accountability concepts are highly relevant for reducing ambiguities between what open development is, and what it is for. The problem is that there are still ambiguities relating to what accountability is and how and why it can be applied to open development. This conceptual review of three purposes of accountability and three groups of accountability concepts has attempted to clarify matters. In general, there is value in pursuing all three purposes and perspectives of accountability mentioned above for open development in four key ways. First, at this juncture, empirical study is warranted to understand accountability practices across open processes and contexts. Second, exploratory studies may also be used to test specific assumptions regarding the purposes of accountability. Third, deeper understandings of accountability practices may also enable researchers to engage more thoroughly with excluded and neglected populations of open development. Fourth, there is a lack of ideas and evidence relating to accountability tools and norms specific to open development. 
Acknowledgements. This research was conducted as part of the Singapore Internet Research Centre's SIRCA III programme and is funded by the International Development Research Centre (IDRC) of Canada.

\section{References}

1. Schedler, A.: Conceptualising accountability. In: Schedler, A., Diamond, L., Plattner, M.F. (eds.) The Self-Restraining State: Power and Accountability in New Democracies, pp. 1327. Lynne Rienner Publishers Inc., London (1999)

2. Smith, M.L., Seward, R.K.: Openness as social praxis. Unpublished manuscript, Ottawa (2016)

3. Reilly, K.M.A., Smith, M.L.: The emergence of open development in a network society. In: Smith, M.L., Reilly, K.M.A. (eds.) Open Development: Networked Innovations in International Development, pp. 15-50. The MIT Press and International Development Research Centre, Ottawa (2013)

4. Sen, A.: Development as Freedom. Oxford University Press, Oxford (2001)

5. Zheng, Y., Stahl, B.C.: Technology, capabilities and critical perspectives: what can critical theory contribute to Sen's capability approach? Ethics Inf. Technol. 13, 69-80 (2011). doi:10.1007/s10676-011-9264-8

6. Buskens, I.: Open development is a freedom song: revealing intent and freeing power. In: Smith, M.L., Reilly, K.M.A. (eds.) Open Development: Networked Innovations in International Development, pp. 327-352. The MIT Press and International Development Research Centre, Ottawa (2013)

7. Smith, M.L., Smith, M., Elder, L.: Open ICT ecosystems transforming the developing world. Inf. Technol. Int. Dev. 6, 65-71 (2010)

8. Singh, P.J., Gurumurthy, A.: Establishing public-ness in the network: new moorings for development - a critique of the concepts of openness and open development. In: Smith, M. L., Reilly, K.M.A. (eds.) Open Development: Networked Innovations in International Development, pp. 173-196. The MIT Press and International Development Research Centre, Ottawa (2013)

9. Gurstein, M.: Open data: empowering the empowered or effective data use for everyone? In: Gurstein's Community Informatics (2010). http://gurstein.wordpress.com/2010/09/02/opendata-empowering-the-empowered-or-effective-data-use-for-everyone/. Accessed $28 \mathrm{Feb}$ 2017

10. Grant, R.W., Keohane, R.O.: Accountability and abuses of power in world politics. Am. Polit. Sci. Rev. 99, 29-43 (2005)

11. Tetlock, P.E.: Accountability: the neglected social context of judgment and choice. Res. Organ. Behav. (1985)

12. Gigler, B.-S., Custer, S., Bailur, S., et al.: Closing the feedback loop: can technology amplify citizen voices?. World Bank, Washington DC (2014)

13. Murillo, M.J.: Evaluating the role of online data availability: the case of economic and institutional transparency in sixteen Latin American nations. Int. Polit. Sci. Rev. 36, 42-59 (2015). doi:10.1177/0192512114541163

14. Aryan, P.R., Ekaputra, F.J., Sunindyo, W.D., Akbar, S.: Fostering government transparency and public participation through linked open government data: case study: Indonesian public information service. In: 2014 International Conference on Data and Software Engineering (ICODSE), Bandung, pp. 1-6. IEEE (2014) 
15. Ebrahim, A.: Accountability in practice: mechanisms for NGOs. World Dev. 31, 813-829 (2003). doi:10.1016/S0305-750X(03)00014-7

16. Frink, D.D., Klimoski, R.J.: Toward a theory of accountability in organizations and human resource management. Res. Pers. Hum. Resour. Manage. 16, 1-51 (1998)

17. Brees, J., Martinko, M.J.: Judgments of responsibility versus accountability. J. Leadersh. Organ. Stud. 22, 443-453 (2015). doi:10.1177/1548051815603127

18. Chambers, R.: Whose Reality Counts?: Putting the First Last, 2nd edn. ITDG Publishing, London (1997)

19. Gaventa, J.: Towards a participatory governance: assessing the transformative possibilities. In: Hickey, S., Mohan, G. (eds.) Participation-From Tyranny to Transformation?: Exploring New Approaches to Participation in Development, pp. 25-39. Zed Books, London (2005)

20. Cooke, B., Kothari, U.: Participation: The New Tyranny? Zed Books, London (2001)

21. Kuriyan, R., Bailur, S., Gigler, B.-S., Park, K.R.: Technologies for transparency and accountability, pp. 1-67 (2011)

22. Leat, D.: Voluntary Organisations and Accountability. Policy Analysis Unit/Billing \& Sons, London (1988)

23. Oliver, D.: Government in the United Kingdom. Open University, Milton Keynes (1991)

24. Hupe, P., Hill, M.: Street-level bureaucracy and public accountability. Public Adm. 85, 279299 (2007). doi:10.1111/j.1467-9299.2007.00650.x

25. Ebrahim, A., Weisband, E.: Global Accountabilities. Cambridge University Press, Cambridge (2007)

26. Peruzzotti, E.: Civil society, representation and accountability: restating current debates on the representativeness and accountability of civic associations. In: Jordan, L., van Tuijl, P. (eds.) NGO Accountability, pp. 43-58. Earthscan Publications Ltd., London (2006)

27. Bovens, M.: The Quest for Responsibility: Accountability and Citizenship in Complex Organisations (Theories of Institutional Design). Cambridge University Press, Cambridge (1998)

28. Handlykken, A.K.: Exploring the politics of Free/Libre/Open Source Software (FLOSS) in the context of contemporary South Africa; how are open policies implemented in practice? J. Community Inform. (2012)

29. Canares, M.P.: Opening the local: full disclosure policy and its impact on local governments in the Philippines. In: ICEGOV 2014, Guimaraes, pp. 89-98. ACM Press (2014)

30. Davies, T., Perini, F.: Researching the emerging impacts of open data: revisiting the ODDC conceptual framework. J. Commun. Inform. (2016)

31. Ohemeng, F.L.K., Ofosu-Adarkwa, K.: One way traffic: the open data initiative project and the need for an effective demand side initiative in Ghana. GovUK 32, 1-10 (2015). doi:10. 1016/j.giq.2015.07.005

32. Daily Pakistan Global: Corruption drives into Uber in Pakistan (2016). https://en. dailypakistan.com.pk/technology/corruption-drives-into-uber-in-pakistan/. Accessed $28 \mathrm{Feb}$ 2016

33. Forte, A., Lampe, C.: Defining, understanding, and supporting open collaboration: lessons from the literature. Am. Behav. Sci. 57, 535-547 (2013). doi:10.1177/0002764212469362

34. Jensen, M.C., Meckling, W.H.: Theory of the firm: managerial behaviour, agency costs, and ownership structure. J. Financ. Econ. 3, 305-360 (1976). doi:10.1002/9780470752135.ch17

35. Shapiro, S.P.: Agency theory. Ann. Rev. Sociol. 31, 263-284 (2005). doi:10.1146/annurev. soc.31.041304.122159

36. Koppell, J.G.: Pathologies of accountability: ICANN and the challenge of "multiple accountabilities disorder". Public Adm. Rev. 65, 94-108 (2005)

37. Ebrahim, A.: Towards a reflective accountability in NGOs. In: Ebrahim, A., Weisband, E. (eds.) Global Accountabilities, pp. 193-223. Cambridge University Press, Cambridge (2007) 
38. Roberts, J.: The possibilities of accountability. Acc. Organ. Soc. 16, 355-368 (1991). doi:10. 1016/0361-3682(91)90027-C

39. Weisband, E.: Conclusion: prolegomena to a post-modern public ethics: images of accountability in global frames (2009). doi:10.1017/CBO9780511490903

40. Bendell, J.: Debating NGO Accountability. United Nations Publications, New York and Geneva (2006)

41. Zheng, Y., Stahl, B.C.: A critical capability approach to open development. Strengthening Information Society Research Capacity Alliance (SIRCA), Singapore (2016). http://www. sirca.org.sg/wp-content/uploads/2015/08/Zheng_WhitePaper.pdf. Accessed 28 Feb 2017

42. Sharp, S.: FOSS Heartbeat. In: sarahsharp.github.io. https://sarahsharp.github.io/fossheartbeat/. Accessed 28 Feb 2017

Open Access This chapter is licensed under the terms of the Creative Commons Attribution 4.0 International License (http://creativecommons.org/licenses/by/4.0/), which permits use, sharing, adaptation, distribution and reproduction in any medium or format, as long as you give appropriate credit to the original author(s) and the source, provide a link to the Creative Commons license and indicate if changes were made.

The images or other third party material in this chapter are included in the chapter's Creative Commons license, unless indicated otherwise in a credit line to the material. If material is not included in the chapter's Creative Commons license and your intended use is not permitted by statutory regulation or exceeds the permitted use, you will need to obtain permission directly from the copyright holder. 